\title{
Injection practices in 2011-2015: a review using data from the demographic and health surveys (DHS)
}

Tomoyuki Hayashi ${ }^{1,2^{*}}$, Yvan J.-F. Hutin ${ }^{1}$, Marc Bulterys ${ }^{1}$, Arshad Altaf ${ }^{3}$ and Benedetta Allegranzi ${ }^{4}$

\begin{abstract}
Background: Reuse of injection devices to give healthcare injections decreased from 39.8 to 5.5\% between 2000 and 2010, but trends since 2011 have not been described. We reviewed results of Demographic and Health Surveys (DHS) to describe injection practices worldwide from 2011 to 2015.

Methods: We searched the DHS Internet site for data published on injection practices conducted in countries from 2011 to 2015, extracted information on frequency (number of healthcare injections per person in the last 12 months) and safety (proportion of syringes and needles taken from a new, unopened package). We compared gender groups and WHO regions in terms of frequency and safety. For countries with data available, we compared injection practices 2004-2010 and 2011-2015.

Results: Since 2011, 40 of 92 countries (43\%) that conducted DHS surveys reported on injection practices. On average, the frequency of injection was 1.64 per person per year (from 3.84 in WHO Eastern Mediterranean region to 1.18 in WHO African region). Among those, $96.1 \%$ of injections reportedly used new injection devices (from 90.2\% in the WHO Eastern Mediterranean region to $98.8 \%$ in the WHO Western Pacific region). On average, women received more injections per year (1.85) than men (1.41). Among 16 (40\%) countries with data in 2004-2010 and 2011-2015, 69\% improved in terms of safety. The annual number of unsafe injections reduced in $81 \%$ of countries. In Pakistan, the number of unsafe injections was the highest and did not decrease between 2006 and 2012.

Conclusions: Injection practices have continued to improve in most countries worldwide, although the Eastern Mediterranean region in particular still faces unsafe practices that are not improving. Further efforts are needed to eliminate unsafe injection practices in health care settings, including through the use of reuse-prevention devices. Despite some limitations, DHS is an easily available method to measure progress over time.
\end{abstract}

Keywords: Healthcare injection, Demographic and health surveys, DHS, Syringe, Needle, Injection practice, Injection device, Unsafe injection

\section{Background}

A safe injection never harms the recipient, does not expose the provider to avoidable risks and does not result in any waste that is dangerous to other people [1]. The World Health Organization (WHO) estimated that in 2000, 16 billion healthcare injections were given each

\footnotetext{
* Correspondence: hayasix0917@gmail.com

'Global Hepatitis Programme, World Health Organization, Geneva, Switzerland

${ }^{2}$ Department of Gastroenterology, Kanazawa University and WHO Collaborating Center for Chronic Hepatitis and Liver Cancer, Kanazawa, Ishikawa, Japan

Full list of author information is available at the end of the article
}

year in developing and transitional countries [2]. Of these, 90-95\% were for therapeutic purposes, while 5$10 \%$ were immunizations [2].

Injections are often used unnecessarily when oral medicine could be equally effective [3]. WHO estimated that in $2000,39.8 \%$ of injections were given with devices reused in the absence of sterilization [2]. Health care injections given with re-used equipment expose patients to infections with bloodborne pathogens, including hepatitis B virus (HBV) [4], hepatitis C virus (HCV) [5], and human immunodeficiency virus (HIV) [6]. Overuse of injections to administer medicines amplifies the risk

(C) The Author(s). 2019 Open Access This article is distributed under the terms of the Creative Commons Attribution 4.0 International License (http://creativecommons.org/licenses/by/4.0/), which permits unrestricted use, distribution, and 
of transmission. WHO estimated that in 2000, overuse and unsafe use of healthcare injections caused $30 \%$ of new infections with HBV ( 21 million), $41 \%$ of new infections with $\mathrm{HCV}$ (2 million), and 9\% of new infections with HIV (260,000, annually) [7].

Since 2000, WHO worked on the establishment of policies for the safe and appropriate use of injections worldwide. The Safe Injection Global Network (SIGN) regrouped efforts from all stakeholders, including international organizations, governments, nongovernmental organization, civil society, and industry [8]. From 2004, the Demographic and Health Surveys (DHS) started to include data on injection practices for surveys conducted in several countries [9]. DHS are nationally representative population-based surveys of adult population with large sample sizes (e.g., > 5,000 households). The DHS Programme has provided technical assistance to more than 300 surveys in over 90 countries, advancing global understanding of health and population trends. New questionnaire items included injection frequency (the average number of healthcare injections reported per person per year) and injection safety (whether for the last healthcare injection, the syringe and needle came from a new, unopened package). In the year 2010, WHO commissioned an update of the 2000 injection practices estimates. This 2010 review which largely used DHS data. The results indicated that between 2000 and 2010, the proportion of reuse of injection devices dropped from 39.8 to $5.5 \%$. Meanwhile, the frequency of use of injection to administer medications had not decreased [10]. Overuse and unsafe use of injections still led to transmission of bloodborne pathogens, although less so than in 2000 . From 2000 to 2010 , despite a 13\% population growth, there was an estimated reduction of 87 and $83 \%$, respectively, in the absolute numbers of HIV and HCV infections transmitted through healthcare injections. For HBV, the reduction was more marked (91\%) due to the additional impact of vaccination [11].

In 2016, WHO published injection safety guidelines recommending safety engineered injection devices to eliminate unsafe injections [12]. The WHO policy document specifically addressed the use of these devices for therapeutic injections. Further, WHO launched a comprehensive behaviour change and multimodal implementation strategy addressing different audiences and stakeholders to facilitate adoption of the injection safety recommendations according to a strategy in 2017 [13]. A package of tools (available online) promote communication for behaviour change among patients and health care workers to reduce injection overuse and ensure safety. More recent and higher quality data are needed to monitor the evolution of injection safety since 2011, including to track progress before and after the launch of the WHO policy [14]. However, systematic reviews can be costly and time consuming. The ongoing collection of injection practices information within DHS provided an opportunity to obtain new estimates easily and rapidly. The objectives were to describe injection practices since 2011, including heterogeneity by region and gender, and to determine if injection safety has improved since 2011.

\section{Methods}

We reviewed healthcare injection practices worldwide in terms of frequency and safety according to the indicators included in DHS since 2011 and until 2015. The datasets analyzed during the current review are available in the DHS Program webpage (https://www.dhsprogram.com/). If countries surveyed since 2011 had a prior DHS survey data including injection practice up to 2010, we included the prior survey to compare data in 2004-2010 and in 2011-2015.

\section{Data collection during the DHS surveys}

DHS questionnaires were conducted in countries and adapted from template survey instruments developed by the DHS programme to reflect the population and health issues relevant to each country. The questionnaire was translated into each native language. A nationally representative sample of households (women age 15-49 and men age $15-49,54$, or 59) was eligible for individual interviews that were performed individually. We focused on two template questions. These were 'have you had an injection for any reason in the last 12 months? If yes, how many injections have you had?' and 'the last time you got an injection from a health worker, did he/she take the syringe and needle from a new, unopened package?'. When considering DHS questionnaire items, we used the term 'frequency' to refer to the average number of health care injections per person in the last 12 months, and used the term 'safety' to refer to the proportion of injections for which the respondent mentioned the syringe and needle had been taken from a new, unopened package.

\section{Search for DHS surveys}

We accessed the homepage of DHS Program to search all DHS final reports in 2011-2015 for data on injection practices. If the surveyed year spanned over two years (such as 2015-16), we considered the survey to have been conducted in the year it was initiated. When the data was available, we also searched the survey data conducted in 2004-2010 in the same country for comparison. 


\section{Data abstraction}

We extracted the data on frequency and safety. The denominator for frequency was the total number of respondents. The denominator for safety was the number of respondents who had received at least one health care injection in the last 12 months.

\section{Data analysis}

Some countries had only information on injections received in the last six months. In that case, we doubled frequency to adjust for the different referent period as done in prior reviews [2]. We multiplied the number of injections received by the proportion unsafe to calculate the number of unsafe injection per person per year [(the average number of health care injections per person in the last 12 months) $\times\{1$-(the proportion of injections from a new package)\}]. For countries that had surveys conducted at the subnational level, we calculated the average value of the subnational surveys.

We combined the data from the various surveys to estimate the global situation in terms of frequency and safety. We compared gender groups, regions, and countries in terms of the number of unsafe injections. For countries that had more than two DHS surveys since 2004, we compared practices in 2004-2010 and in 2011-2015 in terms of safety and frequency. If there were multiple surveys up to 2010, we adopted the most recent one to reflect on the most recent evolution. For countries that only had data on women, we restricted the comparison to women for the two time periods.

\section{Results}

\section{DHS surveys available}

As of December 2017, we identified 92 countries with DHS data available between 2004 and 2015. Among these countries, $43 \%$ (40/92 countries) included injection safety data for 2011-2015 (Table 1). Among these, 40 countries, $40 \%$ (16/40 countries) also had the data in 2004-2010 available for comparison over time (Table 1).

\section{Safety and frequency}

Overall, respondents reported 1.64 injections per person per year $(N=840,711)$ in $2011-2015$. Of these, $96.1 \%$ $(N=279,620)$ were reported to have been given with devices taken out of a new packet (i.e. were considered to be safe).

\section{Regional variations}

The Eastern Mediterranean Region (EMR) had the highest number of unsafe injections $(0.376$ per person per year). EMR also had the highest average number of health care injections per person in the last 12 months and the lowest proportion of injections with devices from a new package (Table 2 and Fig. 1). EMR was followed by the South-East Asia Region (SEAR, 0.178 per person per year), the European Region (EUR, 0.085 per person per year), the African Region (AFR, 0.039 per person per year), the region of the Americas (AMR, 0.020 per person per year), and the Western Pacific Region (WPR, 0.019 per person per year). Detailed injection practices in counties according to DHS surveys conducted in 2011-2015 is reported in Table 3.

\section{Analysis by gender}

The average number of health care injections per person in the last 12 months was higher in women $(1.85$ per person per year, sample size: 575,490$)$ than in men $(1.41$ per person per year, sample size: 265,221 ). However, the proportion of injection devices taken from a new package was almost the same in women $(96.2 \%$, sample size: $202,969)$ and in men $(96.0 \%$, sample size: 76,651$)$. Overall, the number of unsafe injections per person and per year was 0.071 in women and 0.056 in men.

\section{Evolution over time}

Among the 16 countries with 2004-2010 and 20112015 data, the average annual number of injections decreased from 1.44 (sample size: 252,513) to 1.25 (sample size: 317,886$)$. Similarly, the average proportion of safe injection increased from 95.9\% (sample size: 70,953) to 97.0\% (sample size: 98,103, Table 4). In terms of frequency, of 16 countries, 9 (56\%) had improved (average improvement: 0.49 , range: $0.10-2.35), 1$ had not changed, and $6(38 \%)$ had deteriorated (average deterioration: 0.18 , range: $0.05-0.30$ ). In terms of safety, 11 of 16 countries (69\%) improved (average improvement: 1.7\%, range: $0.2-5.1 \%$ ) and 5 of 16 countries (31\%) deteriorated (average deterioration: 0.8\%, range: $0.1-1.4 \%$ ). The annual number of unsafe injections improved in $81 \%$ (13 of 16 countries) and deteriorated in 19\% (3 of 16 countries). In Pakistan, the number of unsafe injections was the highest among the 16 countries. Among females for whom data was available in the two time periods. The number of unsafe injections did not change substantially between 2006 (0.71 per person per year) and $2012(0.80$ per person per year).

\section{Discussion}

In 2010, a review of injection practices globally reported improvement in injection safety following the implementation of joint efforts from WHO, partners of the Safe Injection Global Network, other agencies and countries $[10,11]$. However, it also pointed to the absence of improvement in reducing the frequency of health care injections annually. This new rapid review provides an indication of the evolution of the situation since 2011, and sheds light on the additional progress and setbacks. 
Table 140 countries with injection practices data -in DHS surveys conducted between 2011 and 2015 and 16 countries with corresponding prior data (2004-2010). As of December 2017, we identified 92 countries with DHS data available between 2004 and 2015. Among these countries, 43\% (40/92 countries) included injection safety data for 2011-2015. Among these, 40 countries, $40 \%$ (16/40 countries) also had the data in 2004-2010 available for comparison over time

\begin{tabular}{|c|c|c|c|}
\hline \multirow[t]{2}{*}{ Region } & \multirow[t]{2}{*}{ Country } & \multirow{2}{*}{$\begin{array}{l}\text { Year with data available } \\
\text { (2011-2015) }\end{array}$} & \multirow{2}{*}{$\begin{array}{l}\text { Year with data available } \\
\text { (2004-2010) }\end{array}$} \\
\hline & & & \\
\hline African & Benin & 2011 & $2006^{c}$ \\
\hline African & Cameroon & 2011 & No data \\
\hline African & Congo & 2011 & No data \\
\hline African & Cote d'Ivoire & 2011 & No data \\
\hline African & Equatorial Guinea & 2011 & No data \\
\hline African & Ethiopia & 2011 & 2005 \\
\hline African & Mozambique & 2011 & No data \\
\hline African & Uganda & 2011 & 2006 \\
\hline African & Comoros & 2012 & No data \\
\hline African & Gabon & 2012 & No data \\
\hline African & Mali & 2012 & $2006^{c}$ \\
\hline African & Niger & 2012 & No data \\
\hline African & Gambia & 2013 & No data \\
\hline African & Liberia & 2013 & 2007 \\
\hline African & Namibia & 2013 & 2006 \\
\hline African & Nigeria & 2013 & 2008 \\
\hline African & Sierra Leone & 2013 & 2008 \\
\hline African & Togo & 2013 & No data \\
\hline African & Zambia & 2013 & 2007 \\
\hline African & Chad & 2014 & No data \\
\hline African & Ghana & 2014 & 2008 \\
\hline African & Kenya & 2014 & No data \\
\hline African & Lesotho & 2014 & No data \\
\hline African & Rwanda & 2014 & 2005,2010 \\
\hline African & Tanzania & 2015 & $2004,2010^{c}$ \\
\hline African & Zimbabwe & 2015 & 2005,2010 \\
\hline Americas & Honduras $^{\mathrm{a}}$ & 2011 & No data \\
\hline Americas & Haiti & 2012 & 2005 \\
\hline Americas & Dominican Republic & 2013 & No data \\
\hline Eastern Mediterranean & Pakistan & 2012 & $2006^{c}$ \\
\hline Eastern Mediterranean & Yemen & $2013^{c}$ & No data \\
\hline Eastern Mediterranean & Afghanistan & 2015 & No data \\
\hline European & Kyrgyz Republic & 2012 & No data \\
\hline European & Tajikistan & $2012^{c}$ & No data \\
\hline European & Armenia & 2015 & 2010 \\
\hline South-East Asia & Nepal & 2011 & No data \\
\hline South-East Asia & Indonesia & 2012 & No data \\
\hline South-East Asia & India $^{\mathrm{b}}$ & 2015 & No data \\
\hline South-East Asia & Myanmar & 2015 & No data \\
\hline Western Pacific & Cambodia & 2014 & No data \\
\hline
\end{tabular}

anly frequency data available (no safety data)

${ }^{b}$ Average value of the five areas surveyed

c Only female data available (Only female data used in the comparisons)

The most recent DHS surveys suggested that in 20112015 , the trend towards improvement of injection practices continued. However, injection frequency and safety continued to vary widely by region. The WHO EMR has the highest number of injections and the highest proportion of unsafe injections, followed by the WHO SEAR. 
Table 2 Injection practices in WHO regions according to DHS surveys conducted in 2011-2015. The Eastern Mediterranean Region had the highest number of unsafe injections (0.376 per person per year). The Eastern Mediterranean Region also had the highest average number of health care injections per person in the last 12 months and the lowest proportion of injections with devices from a new package. The Eastern Mediterranean Region was followed by the South-East Asia Region (0.178 per person per year), the European Region (0.085 per person per year), the African Region (0.039 per person per year), the region of the Americas (0.020 per person per year), and the Western Pacific Region (0.019 per person per year)

\begin{tabular}{|c|c|c|c|c|c|}
\hline \multirow[b]{2}{*}{ Country } & \multicolumn{2}{|l|}{ Frequency } & \multicolumn{2}{|l|}{ Safety } & \multirow{2}{*}{$\begin{array}{l}\text { Number } \\
\text { of unsafe } \\
\text { injections } \\
\text { per } \\
\text { person } \\
\text { per year }\end{array}$} \\
\hline & Health care injections per person per year & Sample size & Use of an unopened syringe or needle & Sample size & \\
\hline African & 1.18 & 466,836 & $96.7 \%$ & 144,115 & 0.039 \\
\hline Americas & 1.28 & 73,335 & $98.4 \%$ & 12,951 & 0.020 \\
\hline Eastern Mediterranean & 3.84 & 82,347 & $90.2 \%$ & 32,467 & 0.376 \\
\hline European & 2.92 & 29,148 & $97.1 \%$ & 6,881 & 0.085 \\
\hline South-East Asia & 2.66 & 166,277 & $93.3 \%$ & 75,233 & 0.178 \\
\hline Western Pacific & 1.60 & 22,768 & $98.8 \%$ & 7,973 & 0.019 \\
\hline Total & 1.64 & 840,711 & $96.1 \%$ & 279,620 & 0.064 \\
\hline
\end{tabular}

${ }^{\mathrm{a}}$ Number of injections multiplied by the proportion unsafe

The number of unsafe healthcare injection in the WHO EMR was also the highest in the world in 2000 (2.96 per person per year) [2] and in 2010 (0.57 per person per year) [10]. Many injections are administered by private health care providers who may not have formal medical qualification in these regions. In such informal situations, the attitude of the healthcare provider also promotes the abuse of injections. Compliance of standard treatment guidelines is not common. To meet the demands of the user, injections are often utilized on an "ad hoc" basis to administer drug mixtures such as antibiotics, analgesics, vitamins or antihistamines $[15,16]$. If safe injections were administered, reduction of injection overuse would only be a matter of facilitating rational use of medicines [17]. However, reuse of syringes frequently leads to transmission of bloodborne pathogens [18-25]. In EMR and SEAR, especially India and Pakistan, blood-borne pathogens are prevalent and can

Region of Eastern Mediterranean

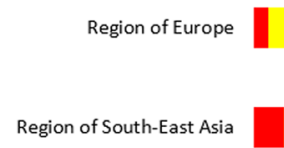

Region of Western Pacific |

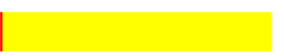

- Unsafe injections

Safe injections

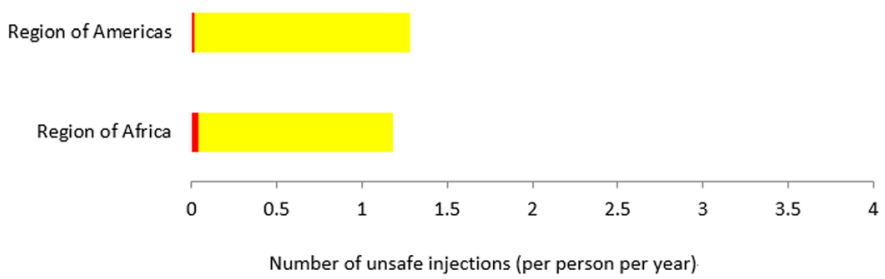

Fig. 1 Annual number of safe and unsafe injections, by WHO region, DHS surveys conducted in 2011-2015. The Eastern Mediterranean Region had the highest number of unsafe injections ( 0.376 per person per year). The Eastern Mediterranean Region also had the highest average number of health care injections per person in the last 12 months and the lowest proportion of injections with devices from a new package. The Eastern Mediterranean Region was followed by the South-East Asia Region ( 0.178 per person per year), the European Region ( 0.085 per person per year), the African Region ( 0.039 per person per year), the region of the Americas ( 0.020 per person per year), and the Western Pacific Region ( 0.019 per person per year) 
Table 3 Injection practices in counties according to DHS surveys conducted in 2011-2015. Detailed injection practices in counties according to DHS surveys conducted in 2011-2015. The data was divided by country from Table 2

\begin{tabular}{|c|c|c|c|c|c|}
\hline \multirow[b]{2}{*}{ Region } & \multirow[b]{2}{*}{ Country } & \multicolumn{2}{|l|}{ Frequency } & \multicolumn{2}{|l|}{ Safety } \\
\hline & & $\begin{array}{l}\text { Health care injections per person per } \\
\text { year }\end{array}$ & $\begin{array}{l}\text { Sample } \\
\text { size }\end{array}$ & $\begin{array}{l}\text { Use of an unopened syringe or } \\
\text { needle }\end{array}$ & $\begin{array}{l}\text { Sample } \\
\text { size }\end{array}$ \\
\hline African & Benin & 0.60 & 21,739 & $94.7 \%$ & 3,419 \\
\hline African & Cameroon & 1.80 & 14,648 & $97.6 \%$ & 5,883 \\
\hline African & Congo & 1.80 & 15,964 & $98.3 \%$ & 4,042 \\
\hline African & Cote d'Ivoire & 1.20 & 15,195 & $96.8 \%$ & 5,767 \\
\hline African & Equatorial Guinea & 2.60 & 5,400 & $96.1 \%$ & 2,063 \\
\hline African & Ethiopia & 1.35 & 30,625 & $97.6 \%$ & 10,053 \\
\hline African & Mozambique & 0.50 & 17,780 & $94.6 \%$ & 3,196 \\
\hline African & Uganda & 1.65 & 10,969 & $95.6 \%$ & 4,328 \\
\hline African & Comoros & 0.60 & 7,496 & $91.7 \%$ & 1,486 \\
\hline African & Gabon & 1.20 & 14,076 & $97.6 \%$ & 4,626 \\
\hline African & Mali & 0.70 & 14,823 & $98.0 \%$ & 3,231 \\
\hline African & Niger & 0.80 & 15,088 & $96.8 \%$ & 5,539 \\
\hline African & Gambia & 0.90 & 14,054 & $97.5 \%$ & 4,438 \\
\hline African & Liberia & 1.65 & 13,357 & $98.1 \%$ & 5,372 \\
\hline African & Namibia & 0.85 & 13,197 & $97.2 \%$ & 4,028 \\
\hline African & Nigeria & 1.10 & 56,307 & $97.3 \%$ & 14,097 \\
\hline African & Sierra Leone & 1.95 & 23,920 & $97.4 \%$ & 9,581 \\
\hline African & Togo & 1.15 & 13,956 & $94.5 \%$ & 4,207 \\
\hline African & Zambia & 0.75 & 31,184 & $97.0 \%$ & 6,956 \\
\hline African & Chad & 2.05 & 11,433 & $94.1 \%$ & 4,124 \\
\hline African & Ghana & 0.70 & 13,784 & $98.0 \%$ & 4,030 \\
\hline African & Kenya & 1.45 & 27,444 & $98.5 \%$ & 10,877 \\
\hline African & Lesotho & 0.75 & 9,552 & $95.2 \%$ & 2,764 \\
\hline African & Rwanda & 1.30 & 19,714 & $99.2 \%$ & 10,977 \\
\hline African & Tanzania & 0.90 & 16,780 & $97.6 \%$ & 4,786 \\
\hline African & Zimbabwe & 0.50 & 18,351 & $97.6 \%$ & 4,245 \\
\hline Americas & Honduras $^{a}$ & 1.60 & 29,877 & No data & No data \\
\hline Americas & Haiti & 0.60 & 23,780 & $98.4 \%$ & 5,720 \\
\hline Americas & $\begin{array}{l}\text { Dominican } \\
\text { Republic }\end{array}$ & 1.65 & 19,678 & $98.5 \%$ & 7,231 \\
\hline $\begin{array}{l}\text { Eastern } \\
\text { Mediterranean }\end{array}$ & Pakistan & 5.15 & 16,692 & $87.7 \%$ & 9,875 \\
\hline $\begin{array}{l}\text { Eastern } \\
\text { Mediterranean }\end{array}$ & Yemen $^{\mathrm{b}}$ & 3.30 & 25,434 & $91.8 \%$ & 8,989 \\
\hline $\begin{array}{l}\text { Eastern } \\
\text { Mediterranean }\end{array}$ & Afghanistan & 2.80 & 40,221 & $91.8 \%$ & 13,603 \\
\hline European & Kyrgyz Republic & 2.55 & 10,621 & $96.5 \%$ & 2,720 \\
\hline European & Tajikistan $^{b}$ & 7.10 & 9,656 & $98.7 \%$ & 2,963 \\
\hline European & Armenia & 1.20 & 8,871 & $97.1 \%$ & 1,198 \\
\hline South-East Asia & Nepal & 1.20 & 16,795 & $98.3 \%$ & 5,430 \\
\hline South-East Asia & Indonesia & 1.35 & 54,913 & $90.0 \%$ & 23,557 \\
\hline South-East Asia & India ${ }^{c}$ & 5.82 & 76,947 & $86.5 \%$ & 36,902 \\
\hline South-East Asia & Myanmar & 2.25 & 17,622 & $98.7 \%$ & 9,344 \\
\hline
\end{tabular}


Table 3 Injection practices in counties according to DHS surveys conducted in 2011-2015. Detailed injection practices in counties according to DHS surveys conducted in 2011-2015. The data was divided by country from Table 2 (Continued)

\begin{tabular}{|c|c|c|c|c|c|}
\hline \multirow[b]{2}{*}{ Region } & \multirow[b]{2}{*}{ Country } & \multicolumn{2}{|l|}{ Frequency } & \multicolumn{2}{|l|}{ Safety } \\
\hline & & $\begin{array}{l}\text { Health care injections per person per } \\
\text { year }\end{array}$ & $\begin{array}{l}\text { Sample } \\
\text { size }\end{array}$ & $\begin{array}{l}\text { Use of an unopened syringe or } \\
\text { needle }\end{array}$ & $\begin{array}{l}\text { Sample } \\
\text { size }\end{array}$ \\
\hline Western Pacific & Cambodia & 1.60 & 22,768 & $98.8 \%$ & 7,973 \\
\hline
\end{tabular}

${ }^{a}$ Only frequency data available

b Only female data available

c Average value of the five areas surveyed

be transmitted, around $1.7-5.6 \%$ for HBV [26], 0.5-3.8\% for HCV [27], and $0.3-0.1 \%$ for HIV [28]. For instance, unsafe health care injections remain a key driver of the HCV epidemic in Pakistan [29]. It is also a possible vector of HIV infection [30]. This could be prevented as patients' knowledge regarding transmission of bloodborne pathogens drives consumer demand for new syringes $[31,32]$.

According to DHS, women generally received more injections than men. The reasons for this may include obstetrical and gynecological conditions, including contraception, delivery, and prevention of maternal and neonatal tetanus. DHS data also suggest that there is no difference in injection safety between women and men. Some of the injections received by women could be received through programmes such as immunization or contraceptive treatment rather than informal health care. However, the absolute number of unsafe injections was higher in women than in men. Actually, exposure to healthcare (e.g. health care injections, hospitalizations and pregnancies) has been associated with $\mathrm{HCV}$ infection among women in Pakistan [33, 34]. Addressing this issue has the potential to reduce gender inequalities in injection safety. Since 1999, the principle of "bundling" has been proposed to ensure the safety of injections given through key public health programmes, so that the sources of financing of immunization and contraception commodities also pay for safe injection devices and safety boxes for disposal of used injection equipment [35]. Bundling refers to the concept of a theoretical "bundle" which comprises each of the following items: 1) good quality vaccines, 2) auto-disable syringes, and 3) safety boxes. "Bundling" does not have physical connotation and has no implication that items should be "packaged" together [36]. In EPI, application of the concept of bundling represents a substantial incremental cost as vaccines are inexpensive. However, implementation is facilitated since immunization services are usually centrally funded [37]. For therapeutic injections, the concept of bundling was generalized into broader "guiding principles for injection device security" [38]. The incremental cost is much lower because medicines are usually more expensive than the injection device required to inject them [39]. However, implementation is challenging since the funding of health care services is usually more fragmented.

Comparison of the 2004-2010 and 2011-2015 periods in 16 countries with available data suggested an improvement in many countries. Concerted efforts of ministries of health, local health facilities, non-profit organizations, and donors may explain some of the progress. However, in Pakistan, Uganda and Zambia, the number of unsafe injections did not change substantially since 2011. Pakistan is a country with a rapidly increasing population. The effects of the reduction in unsafe injections might be reduced by the population growth in some densely populated regions. However, in theory, the scale up of safe injections could be more cost effective and positively associated with infections averted in growing populations [40]. This is important because Pakistan has the second highest number of $\mathrm{HCV}$ infections in the world [27].

Injection-associated transmission of bloodborne pathogens can be prevented through the development of a strategy to reduce injection overuse and achieve injection safety and its implementation by a national coalition [41]. Achieving this goal necessitates the establishment of a national multidisciplinary cooperation between the

Table 4 Comparison of injections practices up to 2010 and since 2011 in the 16 countries where DHS data were available for comparison. Among the 16 countries with 2004-2010 and 2011-2015 data, the average annual number of injections decreased from 1.44 (sample size: 252,513) to 1.25 (sample size: 317,886). Similarly, the average proportion of safe injection increased from 95.9\% (sample size: 70,953 ) to $97.0 \%$ (sample size: 98,103 )

\begin{tabular}{|c|c|c|c|c|}
\hline & \multicolumn{2}{|l|}{ Frequency } & \multicolumn{2}{|l|}{ Safety } \\
\hline & Health care injections per person per year & Sample size & Use an unopened syringe or needle & Sample size \\
\hline Up to $2010^{a}$ & 1.44 & 252,513 & $95.9 \%$ & 70,953 \\
\hline Since 2011 & 1.25 & 317,866 & $97.0 \%$ & 98,103 \\
\hline
\end{tabular}

${ }^{a}$ Use only more recent data if there are multiple data 
Ministry of Health and stakeholders such as private healthcare providers and non-governmental organizations. Changing behavior strategies towards consumers and the public, private and general healthcare professionals should be strongly supported. To implement such a strategy, WHO suggests a package of tools available online for safe and appropriate injection use in planning, implementation and evaluation of national policies in order to support national policy makers [13]. Equipment and supplies should be provided to eradicate the re-use of syringes and needles without sterilization. Sharps waste should be managed to ensure that disposable syringes and needles are not re-used and do not lead to needlestick injuries [38]. In addition, since 2016, WHO recommends a policy to prefer the use of sharp injury protection syringes for intramuscular, intradermal and subcutaneous injections over the use of re-use prevention syringes for intramuscular, intradermal and subcutaneous injections [12]. Syringes with sharps injury prevention features reduce the incidence of needlestick injuries [42]. Healthcare workers perceive injection safety devices to be generally easy to use, safe, and tolerated by patients [43]. Rapid implementation of this policy could address residual injection safety issues in resource-limited settings where unsafe practices persist.

Our review and analysis of existing data have a number of limitations. Some limitations are inherent to the methods used by DHS. Survey respondents were asked whether they had received any injections from a health worker in last 6 or 12 months before the survey. Therefore, they might not have noticed or remembered precisely whether the injection they are receiving was given with a new needle and syringe from an unopened package when interviewed months later (recall bias). Furthermore, the respondents might tend to answer questions in a manner that will be viewed socially favorable because the data was collected by questionnaire (social desirability bias). There are also limitations due to our review methods. First, we did not calculate confidence intervals, did not perform statistical comparisons and did not model regional or global estimates. Calculation of confidence intervals in statistical analyses is based on the assumption of random sampling, yet the countries that were included in the DHS programme were not chosen at random. Further, the low proportion of unsafe injections, the lack of variability in terms of income groups and the limited sample size of countries included would have limited efforts to model regional and global estimates. Second, we used only one data source (DHS), which provides limited evidence in some areas while there could be other data sources for injection safety. Third, doubling the six month recall may overestimate the response that would've been generated by asking people to recall 12 months. Fourth, there are different samples sizes by the different regions or countries, therefore, it is hard to compare across regions precisely. Finally, there is large variation globally by region and a lack of data from many countries. Of 92 countries with DHS data available, injection safety data were available from only 40 countries, and these differed from the 16 countries with 2004-2010 data. Overall, our estimation is an imperfect reflection of the current status worldwide, and the review is limited to healthcare injections. In many countries non-healthcare injections, including injecting drug use, play an important role in the transmission of bloodborne infections through unsafe injections.

\section{Conclusion}

In conclusion, despite substantial improvements in the past decade, unsafe injections persist worldwide, and continue to vary widely by WHO regions. Women continue to be at higher risk for the consequences of unsafe injections than men. Reported injection practices continued to improve in many countries, but improvements appear to have levelled off since 2011 in some countries, and the situation may have deteriorated in others. On the basis of these findings, we suggest a number of actions. First, strong promotion of the safe and appropriate use of injections is needed, particularly in regions most affected by unsafe injection practices, including the WHO Eastern Mediterranean and South-East Asia regions. Use of WHO recommendations and implementation tools can facilitate implementation [12]. Second, we must address injection safety in the field of reproductive and maternal health services to eliminate any gender inequalities concerning injection safety. Third, stringent efforts are needed to prevent injection-associated infections with bloodborne pathogens through improved technologies. A targeted approach with dissemination of auto-disable and re-use prevention syringes in resourcelimited settings where safety remains an issue and the risk of injection-associated infection is high could eliminate unsafe injections. Finally, there is a need to collect high-quality data on injection safety worldwide and to make use of the available DHS data and other sources of information to justify, guide, and evaluate national safe and appropriate use of injection policies.

\section{Abbreviations \\ AFR: The African Region; AMR: The region of the Americas; DHS: The Demographic and Health Surveys; EMR: The Eastern Mediterranean Region; EUR: The European Region; HBV: Hepatitis B virusHCVhepatitis C virus; HIV: Human immunodeficiency virus; SEAR: The South-East Asia Region; SIGN: The Safe Injection Global Network; WHO: World Health Organization; WPR: The Western Pacific Region}

\section{Acknowledgements}

In addition to the persons listed as authors, the authors wish to acknowledge the comments of Dr. Steve Luby on this manuscript and the staff at global hepatitis programme at WHO are gratefully acknowledged. 


\section{Authors' contributions}

TH collected literatures and wrote the first draft of the manuscript, which was commented by all authors. YJF, MB, AA and BA reviewed the manuscript. All authors read and approved the final manuscript.

\section{Funding}

The authors declare that they have no funding base.

\section{Availability of data and materials}

The raw data we extracted and used for our study can be accessed by visiting the following website, https://www.dhsprogram.com/data/availabledatasets.cfmAfter that, we downloaded "Demographic and Health Survey" of each country and refered to the table on "Prevalence of medical injections".

\section{Ethics approval and consent to participate}

Not applicable.

\section{Consent for publication}

Not applicable.

\section{Competing interests}

The authors declare that they have no competing interests.

\section{Author details}

'Global Hepatitis Programme, World Health Organization, Geneva, Switzerland. ${ }^{2}$ Department of Gastroenterology, Kanazawa University and WHO Collaborating Center for Chronic Hepatitis and Liver Cancer, Kanazawa, Ishikawa, Japan. ${ }^{3}$ Integrated Service Delivery, World Health Organization, Western Pacific Region, Manila, Philippines. ${ }^{4}$ Infection Prevention and Control, World Health Organization, Geneva, Switzerland.

Received: 2 April 2019 Accepted: 22 July 2019

Published online: 27 August 2019

\section{References}

1. Hutin Y, Hauri Y, Chiarello L, Catlin M, Stilwell B, Ghebrehiwet T, et al. Best infection control practices for intradermal, subcutaneous, and intramuscular needle injections. Bull World Health Organ. 2003;81:491-500.

2. Hutin YJ, Hauri AM, Armstrong GL. Use of injections in healthcare settings worldwide, 2000: literature review and regional estimates. BMJ. 2003;327:1075.

3. Reeler AV. Anthropological perspectives on injections: a review. Bull World Health Organ. 2000;78:135-43.

4. Hutin YJF, Harpaz R, Drobeniuc J, Melnic A, Ray C, Favorov M, et al. Injections given in healthcare settings as a major source of acute hepatitis $B$ in Moldova. Int J Epidemiol. 1999:28:782-6.

5. Luby SP, Qamruddin K, Shah AA, Omair A, Pahsa O, Khan AJ, et al. The relationship between therapeutic injections and high prevalence of hepatitis $C$ infection in Hafizabad, Pakistan. Epidemiol Infect. 1997;119:349-56.

6. Hersh BS, Popovici F, Jezek Z, Satten GA, Apetrei RC, Beldescu N, et al. Risk factors for HIV infection among abandoned Romanian children. AIDS. 1993; 7:1617-24.

7. Hauri AM, Armstrong GL, Hutin YJ. The global burden of disease attributable to contaminated injections given in health care settings. Int J STD AIDS. 2004;15:7-16.

8. Hutin YJF, Chen RT. Injection safety : a global challenge. Bull World Health Organ. 1999:77:787-8.

9. USAID. The DHS Program. https://dhsprogram.com/. (Accessed 26 June 2018).

10. Pépin J, Abou Chakra CN, Pépin E, Nault V. Evolution of the global use of unsafe medical injections, 2000-2010. PLoS One. 2013:8:e80948. https://doi. org/10.1371/journal.pone.0080948 eCollection 2013.

11. Pépin J, Abou Chakra CN, Pépin E, Nault V, Valiquette L. Evolution of the global burden of viral infections from unsafe medical injections, 2000-2010. PLoS One. 2014;9:e99677. https://doi.org/10.1371/journal.pone.0099677.

12. World Health Organization 2016. WHO guideline on the use of safetyengineered syringes for intramuscular, intradermal and subcutaneous injections in health care settings. http://apps.who.int/iris/handle/1 0665/250144. Accessed 22 June 2018.
13. World Health Organization 2017. Injection safety tools and resources. http://www.who.int/infection-prevention/tools/injections/en/. Accessed 22 June 2018.

14. Hutin YJ, Bulterys M, Hirnschall GO. How far are we from viral hepatitis elimination service coverage targets? J Int AIDS Soc. 2018;Suppl 2:e25050.

15. Ahmad K. Pakistan:a cirrhotic state? Lancet. 2004;364:1843-4.

16. Altaf A, Shah SA, Shaikh K, Constable FM, Khamassi S. Lessons learned from a community based intervention to improve injection safety in Pakistan. BMC Res Notes. 2013;6:159. https://doi.org/10.1186/1756-0500-6-159.

17. Hutin Y. Evidence and Information for National Injection Safety Policies. 2003. https://edoc.unibas.ch/138/1/DissB_6912.pdf. Accessed 22 June 2018.

18. Talaat M, El-Sayed N, Kandeel A, Azab MA, Afifi S, Youssef FG, et al. Sentinel surveillance for patients with acute hepatitis in Egypt, 2001-04. East Mediterr Health J. 2010;16:134-40.

19. Usman HR, Akhtar S, Rahbar MH, Hamid S, Moattar T, Luby SP. Injections in health care settings: a risk factor for acute hepatitis $B$ virus infection in Karachi, Pakistan. Epidemiol Infect. 2003;130:293-300.

20. Centers for Disease Control and Prevention (CDC). Establishment of a viral hepatitis surveillance system--Pakistan, 2009-2011. MMWR Morb Mortal Wkly Rep. 2011;60:1385-90.

21. Khan AJ, Luby SP, Fikree F, Karim A, Obaid S, Dellawala S, et al. Unsafe injections and the transmission of hepatitis $B$ and $C$ in a periurban community in Pakistan. Bull World Health Organ. 2000;78:956-63.

22. Paez Jimenez A, El-Din NS, El-Hoseiny M, El-Daly M, Abdel-Hamid M, El Aidi $\mathrm{S}$, et al. Community transmission of hepatitis B virus in Egypt: results from a case-control study in greater Cairo. Int J Epidemiol. 2009;38:757-65.

23. Paez Jimenez A, Mohamed MK, Eldin NS, Seif HA, El Aidi S, Sultan Y, et al. Injection drug use is a risk factor for HCV infection in urban Egypt. PLoS One. 2009:4:e7193.

24. Singh J, Bhatia R, Patnaik SK, Khare S, Bora D, Jain DC, et al. Community studies on hepatitis B in Rajahmundry town of Andhra Pradesh, India, 19978: unnecessary therapeutic injections are a major risk factor. Epidemiol Infect. 2000;125:367-75.

25. Narendranathan M, Philip M. Reusable needles-a major risk factor for acute virus B hepatitis. Trop Dr. 1993;23:64-6.

26. World Health Organization 2017, work conducted by the London School of Hygiene \& Tropical Medicine (LSHTM), http://whohbsagdashboard.com/ \#global-strategies. Accessed 22 June 2018.

27. The Polaris Observatory HCV Collaborators. Global prevalence and genotype distribution of hepatitis C virus infection in 2015: a modelling study. Lancet Gastroenterol Hepatol. 2017;2:161-76.

28. UNAIDS, AIDSinfo. http://aidsinfo.unaids.org/. (Accessed 26 June 2018)

29. Lim AG, Qureshi H, Mahmood H, Hamid S, Davies CF, Trickey A, et al. Curbing the hepatitis $C$ virus epidemic in Pakistan: the impact of scaling up treatment and prevention for achieving elimination. Int J Epidemiol. 2018; 47:550-60.

30. Green A. HIV epidemic in children in Pakistan raises concern. Lancet. 2019; 393(10188):2288. https://doi.org/10.1016/S0140-6736(19)31330-3.

31. Dentinger C, Pasat L, Popa M, Hutin YJ, Mast EE. Injection practices in Romania: progress and challenges. Infect Control Hosp Epidemiol. 2004; 25:30-5.

32. Janjua NZ, Mahmood B, Imran KM. Does knowledge about bloodborne pathogens influence the reuse of medical injection syringes among women in Pakistan? J Infect Public Health. 2014;7:345-55.

33. Janjua NZ, Hamza HB, Islam M, Tirmizi SF, Siddiqui A, Jafri W, et al. Health care risk factors among women and personal behaviours among men explain the high prevalence of hepatitis C virus infection in Karachi, Pakistan. J Viral Hepat. 2010;17:317-26.

34. Khan UR, Janjua NZ, Akhtar S, Hatcher J. Case-control study of risk factors associated with hepatitis $C$ virus infection among pregnant women in hospitals of Karachi-Pakistan. Tropical Med Int Health. 2008;13:754-61.

35. World Health Organization 1998. WHO-UNICEF policy statement for mass immunization campaigns, WHO/EPI/LHIS/97.04 Rev.1- replaced by this statement, WHON\&B/99.25. https://apps.who.int/iris/handle/10665/230655. Accessed 22 June 2018.

36. World Health Organization 2003. Safety of injections, WHO-UNICEFUNFPA joint statement on the use of auto-disable syringes in immunization services. http://www.path.org/files/Safety_Injections.pdf. Accessed 22 June 2018.

37. JSI Research and Training Institute Inc. Evaluation of GAVI's Injection Safety Support. Technical report prepared for the GAVI Alliance. Revised 
January 2009. Available at : https://www.gavi.org/library/gavidocuments/evaluations/evaluation-of-gavi-s-injection-safety-support/. (Accessed 14 June 2019).

38. WHO. Guiding principles to ensure injection device security. WHO/HIS/ SDS/2015.30. Available at: https://www.who.int/infection-prevention/ tools/injections/GuidingPrinciple-injection-device-security.pdf. (Accessed 14 June 2019).

39. Logez SM, Hutin YJ, Holloway K, Gray R, Hogerzeil HV. Could the WHO model list of essential medicines do more for the safe and appropriate use of injections? J Clin Pharmacol. 2004;44:1106-13 Review.

40. World Health Organization 2018. Guidelines for the care and treatment of persons diagnosed with chronic HCV infection (ANNEX 4: Modelling analyses). https://www.who.int/hepatitis/publications/hepatitis-cguidelines-2018/en/.

41. World Health Organization 2015. AIDE-MEMOIRE for a national strategy for the safe and appropriate use of injections https://www.who.int/infectionprevention/tools/injections/AideMemoire-injection-safety.pdf?ua=1 . Accessed 22 June 2018.

42. Harb AC, Tarabay R, Diab B, Ballout RA, Khamassi S, Akl EA. Safety engineered injection devices for intramuscular, subcutaneous and intradermal injections in healthcare delivery settings: a systematic review and meta-analysis. BMC Nurs. 2015;14:71. https://doi.org/10.1186/s12912015-0119-1 eCollection 2015.

43. Tarabay R, El Rassi R, Dakik A, Harb A, Ballout RA, Diab B, et al. Knowledge, attitudes, beliefs, values, preferences, and feasibility in relation to the use of injection safety devices in healthcare settings: a systematic review. Health Qual Life Outcomes. 2016;14:102. https://doi.org/10.1186/s12955-016-0505-8.

\section{Publisher's Note}

Springer Nature remains neutral with regard to jurisdictional claims in published maps and institutional affiliations.

Ready to submit your research? Choose BMC and benefit from:

- fast, convenient online submission

- thorough peer review by experienced researchers in your field

- rapid publication on acceptance

- support for research data, including large and complex data types

- gold Open Access which fosters wider collaboration and increased citations

- maximum visibility for your research: over $100 \mathrm{M}$ website views per year

At BMC, research is always in progress.

Learn more biomedcentral.com/submissions 